\title{
Population ecology of endangered white-clawed crayfish (Austropotamobius pallipes s. str.) in a small rhithral river in Germany
}

\author{
F. Wendler ${ }^{(1), \star}$, R. Biss ${ }^{(2)}$, C. Chuchol( ${ }^{(3)}$
}

Received June 4, 2015

Revised July 22, 2015

Accepted August 10, 2015

\section{ABSTRACT}

Key-words: population dynamics, imperiled species, white-clawed crayfish, stone crayfish, Austropotamobius
Sound knowledge on distribution and ecology of imperiled species is an essential prerequisite for effective conservation planning. Here, we report the distribution and autecological traits of a newly discovered population of critically-endangered white-clawed crayfish (Austropotamobius pallipes s. str.) in a small river in southwestern Germany. Using an established crayfish survey protocol, we detected white-clawed crayfish in a river stretch of $4.5 \mathrm{~km}$, with an estimated abundance of $1.4 \pm 0.2$ indiv. $\mathrm{m}^{-2}$. The sex ratio was even and sexual maturity was attained at approximately $25 \mathrm{~mm}$ carapace length $(C L)$. Life-history traits, as assessed using Von Bertalanffy's growth function, indicate a life history most similar to populations in France, with longevity, asymptotic size, and growth performance index being higher in males than in females (11 y, $46 \mathrm{~mm} \mathrm{CL}$, and 2.8 and $9 \mathrm{y}$, $41 \mathrm{~mm} \mathrm{CL}$, and 2.7, for males and females, respectively). Estimated fecundity ranged from 9 to 135 eggs.female ${ }^{-1}$ (mean: $90 \pm 28$ ). White-clawed crayfish were also found in lower reaches of small tributary streams, of which one also featured endangered stone crayfish (Austropotamobius torrentium). A syntopic occurrence of both species was recorded for the first time within a short stretch. Implications for species conservation are discussed.

\section{RÉSUMÉ}

Écologie de la population d'écrevisses à pattes blanches, en danger (Austropotamobius pallipes s. str.) dans un petit torrent en Allemagne

Mots-clés : dynamique des populations, espèces en péril, écrevisse à pattes blanches,
Une bonne connaissance sur la distribution et l'écologie des espèces en péril est une condition essentielle pour la planification d'une conservation efficace. Ici, nous rapportons la distribution et les traits autécologiques d'une population nouvellement découverte d'écrevisses à pattes blanches en danger critique (Austropotamobius pallipes s. str.) dans une petite rivière du sud-ouest d'Allemagne. Utilisant un protocole standard de suivi de l'écrevisse, nous avons détecté l'écrevisse à pattes blanches dans un tronçon de la rivière de $4,5 \mathrm{~km}$, avec une abondance estimée de $1,4 \pm 0,2$ indiv $\cdot \mathrm{m}^{-2}$. Le sexe ratio était de un et la maturité sexuelle est

(1) Biology I, University of Freiburg, Hauptstrasse 1, 79104 Freiburg, Germany

(2) Regierungspräsidium Freiburg, Ref. 56 (Nature Conservation Agency), Bissierstr. 7, 79114 Freiburg, Germany

(3) Fisheries Research Station Baden-Württemberg (LAZBW), Argenweg 50/1, 88085 Langenargen, Germany 
écrevisse

de torrent, Austropotamobius atteinte à environ $25 \mathrm{~mm}$ de longueur de carapace $(\mathrm{CL})$. Les traits de vie, évalués en utilisant la fonction de croissance de Von Bertalanffy, indiquent une histoire de vie très semblable à celle des populations en France, avec la longévité, la taille asymptotique, et l'indice de performance de croissance plus élevés chez les mâles que chez les femelles ( 11 ans, $46 \mathrm{~mm} \mathrm{CL}$, et 2,8 et 9 ans, $41 \mathrm{~mm} \mathrm{CL}$, et 2,7, pour les mâles et les femelles, respectivement). La fécondité estimée variait de 9 à 135 oeufs.femelle ${ }^{-1}$ (moyenne : $90 \pm 28$ ). L'écrevisse à pattes blanches a également été trouvée dans les tronçons inférieurs de petits affluents, dont l'un a également présenté des écrevisses des torrents en danger (Austropotamobius torrentium). Une occurrence syntopique des deux espèces a été enregistrée pour la première fois dans un court tronçon. Les implications pour la conservation des espèces sont discutées.

\section{INTRODUCTION}

Freshwater crayfish (Crustacea: Decapoda: Astacida) represent the largest mobile invertebrates in temperate inland waters and are often considered as keystone species (Nyström, 1999; Holdich, 2003; Stenroth et al., 2008). Native crayfish are a vital part of intact freshwater ecosystems and represent flagship species for conservation efforts (Füreder and Reynolds, 2004; Reynolds and Souty-Grosset, 2012). In this context, they can be used as "umbrellas" for the conservation of sympatric species with similar habitat requirements (Füreder et al., 2003; Reynolds and Souty-Grosset, 2012).

White-clawed crayfish (Austropotamobius pallipes species complex) is the naturally rarest species among the three native crayfishes in Germany. In contrast to the widespread noble crayfish (Astacus astacus) and the stone crayfish (Austropotamobius torrentium), which occurs throughout most of southern Germany (Souty-Grosset et al., 2006; Chucholl and Schrimpf, 2015), the native range of the white-clawed crayfish is naturally restricted to a few catchments of the Upper Rhine drainage in the southwesternmost part of Germany. These occurrences are situated along the western and southern slopes of the Black Forest and represent the northeastern distribution limit of white-clawed crayfish in central Europe (Troschel, 1997; Souty-Grosset et al., 2006). They belong to the western lineage of white-clawed crayfish ( $A$. pallipes s. str.) and exhibit relatively deep divergence to the southern clade, which is considered a distinct species ("A. italicus") by some authors (cf. Trontelj et al., 2005; Chucholl et al., 2015).

White-clawed crayfish are ecologically demanding and mostly occur in pristine or seminatural small streams (1-8 $\mathrm{m}$ in width) with a mosaic of microhabitat patches at moderate elevations of 200 to $550 \mathrm{~m}$ a.s.l in Germany. They are usually restricted to areas without intensive riparian land-use and are frequently associated with natural riparian vegetation composed of broad-leafed trees (Troschel, 1997; Chucholl and Dehus, 2011). Since its discovery in the late 1980s in Germany (Troschel and Dehus, 1993), several white-clawed crayfish populations have disappeared and a recent assessment against the IUCN red list criteria yielded a critically-endangered status for Germany (Chucholl and Dehus, 2011). This coincides with a regression of white-clawed crayfish throughout most of its native range, including an estimated decline of somewhere between $50-80 \%$ in England, France and Italy in the last decade (Füreder et al., 2010).

White-clawed crayfish are generally threatened by human-induced environmental change, including deterioration of habitats and water pollution (Füreder et al., 2010, and citations therein). An additional, imminent threat is the ongoing spread of non-indigenous crayfish species (NICS) in combination with crayfish plague. NICS of North American origin frequently outcompete native crayfish for habitats and act as reservoir hosts for the crayfish plague agent, Aphanomyces astaci, which causes devastating mass mortalities among native crayfish (Souty-Grosset et al., 2006; and citations therein). Particularly dangerous for white-clawed

\footnotetext{
* Corresponding author: franzi.wendler@gmx.de
} 
crayfish is the North American signal crayfish (Pacifastacus leniusculus), which actively invades remaining refuges (Chucholl and Dehus, 2011; Holdich et al., 2014).

Given the critically-endangered status of white-clawed crayfish in Germany, species conservation projects have been initiated (Chucholl and Dehus, 2011). Among other efforts, these include habitat protection, restocking of suitable and safe habitats, and efforts to halt the spread of NICS (cf. Chucholl, 2014). An essential prerequisite for all of these conservation efforts is sound knowledge on distribution, population dynamics, and life history of white-clawed crayfish (cf. Souty-Grosset et al., 2006; Ghia et al., 2015). Previous studies on white-clawed crayfish suggest high latitudinal variation in population ecology (summarized in Ghia et al., 2015) and very little is known about its life history and populations dynamics in Germany.

The aim of this study was therefore to assess the distribution, abundance, and life-history traits of a white-clawed crayfish population in a small river in southwestern Germany in order to further our understanding of this highly endangered species and to facilitate its conservation. In particular, we used an established crayfish survey protocol to explore the spatial extent and abundance of the population, and estimated life-history traits from size-frequency distributions by means of the Von Bertalanffy's Growth Function (VBGF) (cf. Scalici et al., 2008; Ghia et al., 2015).

\section{MATERIALS AND METHODS}

\section{> STUDY SITE}

The study was carried out in the River Brugga, which is a small summer-cool river near the city of Freiburg (southwestern Germany). The white-clawed crayfish population within the river was only recently discovered (unpubl. data Nagel, 2013), although it has been a long known fact that a small tributary stream of the river features an abundant white-clawed crayfish population (Biss, 1996).

The River Brugga has a total length of $15.4 \mathrm{~km}$ and is one of the major tributaries in the headwater area of the Dreisam catchment, which discharges into the Rhine system. It arises at an altitude of $1305 \mathrm{~m}$ a.s.l. from two spring-fed brooks, and flows in a northwestern direction through a basin-shaped valley until its confluence with the River Dreisam at an altitude of $326 \mathrm{~m}$ a.s.l. (Figure 1). The River Brugga represents a rhithral river that is characterized by a high flow-rate, a stony river bed and a mean summer temperature below $20^{\circ} \mathrm{C}$ (Illies, 1961). The investigated stretch was $8.5 \mathrm{~km}$ long and started below the headwater section with high gradients (Figure 1). Width averaged $4.5 \mathrm{~m}$ and depth ranged from $0.1 \mathrm{~m}$ in riffles to $1.2 \mathrm{~m}$ in pools. Mean flow rate in June, 2014 varied from $0.12 \mathrm{~m} \cdot \mathrm{s}^{-1}$ to $1.14 \mathrm{~m} \cdot \mathrm{s}^{-1}$ (Schiltknecht flow measuring device Mini Air 2).

Throughout most of the investigated stretch, the River Brugga features pristine or close to natural conditions with riparian vegetation consisting of deciduous trees, mostly alder (Alnus glutinosa), shrubs and grassland. The structure of the river bank is dominated by alder roots and rocks, often forming overhanging banks. The sparse submerged vegetation in the summer months was dominated by willow moss (Fontinalis spp.). The benthic invertebrate fauna was mostly composed of stonefly (Plecoptera), mayfly (Ephemeroptera) and caddisfly (Trichoptera) larvae, as well as gammarids (cf. Biss, 1996). Amphibians, salmonid fish and bullhead (Cottus gobio) were sporadically noticed.

Physico-chemical water parameters $(\mathrm{pH}$, conductivity, water temperature, and dissolved oxygen levels) were weekly measured from mid-April to mid-June, 2014 (WTW sensors, onset T-Logger). The levels of $\mathrm{pH}$ ranged from 6.2 to 7.0 and conductivity was low with values between 74 and $173 \mu \mathrm{S} \cdot \mathrm{cm}^{-1}$. The recorded water temperature increased from $8.0^{\circ} \mathrm{C}$ in April to $16.1^{\circ} \mathrm{C}$ in June with dissolved oxygen ranging from 5.5 to $14.6 \mathrm{mg} \cdot \mathrm{L}^{-1}$. 


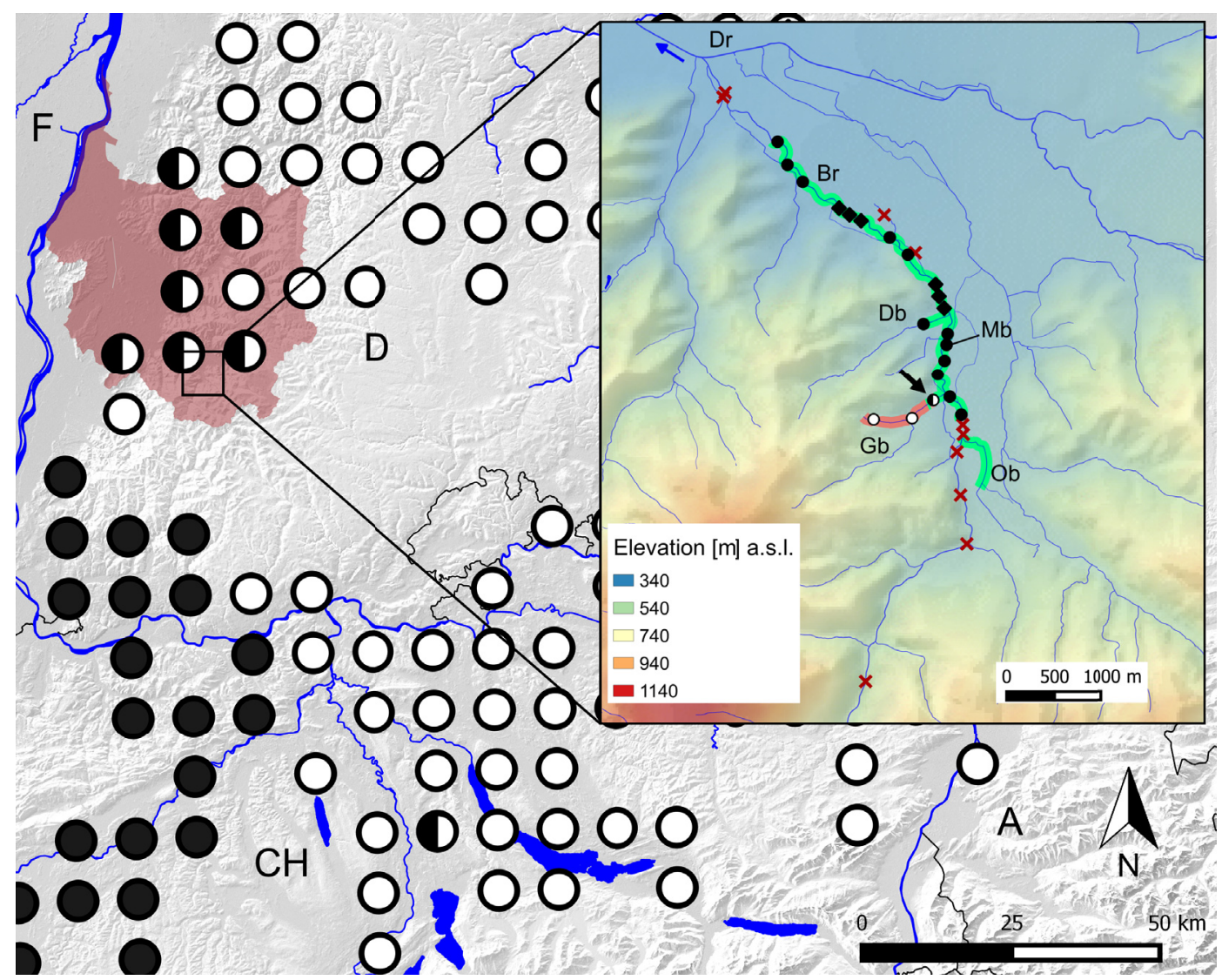

Figure 1

Distribution of A. pallipes s. str. (black dots) and A. torrentium (white dots) in southwestern Germany and neighboring territories shown as presence in $10 \times 10 \mathrm{~km}$ grid cells (EEA reference grid) (background map). The red colored area highlights the River Dreisam/Elz catchment, which represents the only natural range overlap between $A$. pallipes s. str. and A. torrentium. The detail map shows the distribution of $A$. pallipes s. str. (green line) and A. torrentium (red line) within the Brugga (Br) catchment. The arrow indicates the short stretch of syntopic co-occurrence. Red ' $x$ ' mark sampling sites where no crayfish were detected, dots indicate sites with crayfish presence, and diamonds indicate the stretches used for fixed-area sampling. Abbreviations are as follows: Dr - Dreisam; Db - Dietenbach; Gb - Geroldsbach; $\mathrm{Mb}$ - Mühlbach; and Ob-Oberriederbach. Distribution data for the background map were compiled from Chucholl and Dehus (2011) and Stucki and Zaugg (2011).

\section{> CRAYFISH SURVEY}

The first goal was to determine the upstream and downstream limits of the newly discovered white-clawed crayfish population. For this purpose, we surveyed a total of 29 sampling sites for presence of crayfish by way of selective hand capture (cf. Peay, 2003). Sampling sites were selected in areas where conditions are suitable for crayfish. At each sampling site, at least 20 potential shelters (usually boulders or large stones) were carefully searched for hiding crayfish during daytime using hand-held nets. Shelters were selected for large bearing surface area, which increases the probability of occupancy by crayfish (Streissl and Hödl, 2002), and accessibility. To estimate the effectiveness of the sampling strategy, we calculated the probability of capturing at least one crayfish at a sampling site as: $P$ (capture) $=\left(1-(1-F)^{N}\right)$, where $F$ is the frequency of crayfish capture at sites where crayfish are present, and $N$ is the number of inspected shelters per sampling site. Although this estimate does not exclude the possibility of false negatives at sites with very low crayfish density, it can be useful to assess the detection probability at sites with representative abundance (cf. Chucholl and Schrimpf, 2015). 
To assess the population status and life-history traits, we used an established crayfish survey protocol, which was developed for crayfish monitoring within the framework of the EU Habitats Directive (Council Directive 92/43/EEC). This scheme combines fixed-area (pointabundance) with selective (shelter-related) hand-capture by day. In comparison to passive surveying methods (night observation or trapping) this method provides a less biased sample and does not depend on crayfish activity (Pratten, 1980; Peay, 2003). Furthermore, detection of juveniles is rarely possible by way of passive surveying methods. To determine abundance of white-clawed crayfish we selected two river stretches of $150 \mathrm{~m}$ in length. These river stretches were subdivided into three sections of $50 \mathrm{~m}$ in length, ensuring that one of the sections (intensive stretch) offers suitable conditions to crayfish. The two remaining sections (selective stretches) were located downstream and upstream of the intensive stretch. Within the intensive stretch we selected the three most suitable and surveyable areas (habitat patches), ranging in area from 5 to $10 \mathrm{~m}^{2}$. In these habitat patches we did a fixed-area sampling by searching all potential refuges for crayfish. According to Peay (2003) fixed-area sampling gives the closest approximation to local density of crayfish. The selective stretches were surveyed by selective hand capture as outlined above. Shelter use was subsequently calculated as the total number of captured crayfish divided by the total number of inspected shelters. Shelter use correlates with the density of crayfish and can be considered a measure of crayfish abundance (Pearson correlation with logarithmic model: $N=10, R=0.85$, $P<0.001$ ). Sampling according to this survey protocol was done on a total of 26 occasions from mid-April to mid-June, and again from mid-September to mid-October, 2014, to assess life-history traits across one growth season.

\section{> MORPHOMETRIC MEASUREMENTS AND FECUNDITY}

Captured crayfish were sexed, and chelae (propodus) length $(P L)$ and carapace length (from the tip of the rostrum to the posterior margin of the carapace; $C L$ ) were measured to the nearest $0.1 \mathrm{~mm}$ using a slide caliper. Lost or regenerated chelae and other injuries were noted and crayfish were inspected for colonization of branchiobdellid worms. Females were checked for attached eggs and, if present, we took a photograph of the ventral side of the pleon to estimate the total number of eggs following the rationale of Stucki (2002). Because the eggs are attached to the pleopods in several layers, not all of the eggs were visible. Therefore, the number of eggs counted on the photograph was multiplied by the estimated number of egg layers (Stucki, 2002). The number of egg layers was estimated from lateral photographs. Subsequently, the visible part of the eggs in each photograph was re-assessed to identify the multiplier needed for correction. After the examination all crayfish were carefully released near their finding place to avoid downstream drift following sampling.

\section{> GROWTH AND LIFE-HISTORY TRAITS}

To estimate life-history traits, growth was described using the Von Bertalanffy's Growth Function (VBGF), adjusted for seasonal growth in summer and no growth in winter (Pauly and Morgan, 1987; Scalici et al., 2010; Ghia et al., 2015):

$$
C L(t)=C L_{\infty}\left\{1-\exp \left[-k\left(t-t_{0}\right)-(C k / 2 \pi) \sin \left(2 \pi\left(t-t_{\mathrm{s}}\right)\right)\right]\right\}
$$

where $C L(t)$ is the $C L$ at age $t, C L_{\infty}$ the asymptotic length (i.e. the theoretical possible $C L$ ), $k$ the curvature parameter (which determines how fast $C L_{\infty}$ is approached) and $t_{0}$ the initial condition parameter (i.e., the hypothesized age at which $C L$ is zero). The summer point $\left(t_{\mathrm{s}}\right)$ refers to the onset of the first oscillation relative to $t=0$. For practical purposes it was replaced by the winter point $\left(W P=t_{\mathrm{s}}+0.5\right)$, i.e. the time of the year when growth is slowest. The WP was set to mid-winter, and the parameter expressing the amplitude of the seasonal growth oscillation $(C)$ was set arbitrarily to 1, allowing for no growth in winter (cf. Ghia et al., 
2015). $C L_{\infty}$ and $k$ were estimated for each sex from the obtained $1 \mathrm{~mm}$ size-frequency distributions within the ELEFAN I module (non-parametric scoring of the VBGF fit) in the FAOICLARM Stock Assessment Tools software (FiSAT 2 v.1.2.2; Pauly and David, 1981; Gayanilo and Pauly, 1997; Scalici et al., 2010), and $t_{0}$ was assessed by non-linear regression analysis. Longevity $\left(t_{\max }\right)$ was estimated by $t_{\max }=(3 / k)+t_{0}$ (Gayanilo and Pauly, 1997; Scalici and Gherardi, 2007). Finally, the growth performance index $\left(\phi^{\prime}\right)$ was derived from $k$ and $C L_{\infty}$ by applying the equation $\phi^{\prime}=\log (k)+2 \log \left(C L_{\infty}\right)$ (Pauly and Munro, 1984). $\phi^{\prime}$ allows comparison of different stocks' growth performance in terms of length but can also be used to detect biased growth parameter estimates, because populations of the same species show similar values of $\phi^{\prime}$ (Pauly and Munro, 1984).

\section{> STATISTICAL ANALYSES}

All statistical analyses were performed in the software R 3.1.3. (R Core Team, 2015) and SigmaPlot 11.0, except for the life-history analysis, which was performed in FiSAT 2 as outlined above. Prior to statistical analyses, all variables were checked for normality and nonparametric tests were used when appropriate. To assess the effects of crayfish size (CL), sex, and sexual maturity on chelae length $(P L)$, we constructed a multiple linear regression model (MLM) with $P L$ as response variable. CL was implemented as continuous predictor, and sexual maturity and sex were included as factors with two levels. To account for sex-specific growth pattern upon attaining sexual maturity, we included an interaction term between $C L$, sex, and sexual maturity. To reduce model complexity and to arrive at the minimum adequate model, the full model was subjected to stepwise backward selection based on Akaike's information criterion (AIC). The AIC is a model selection tool that measures MLM fit, with a penalty for model complexity (Chambers and Hastie, 1992). The significance of the predictors in the final model was subsequently assessed by analysis of variance (Type II tests) and the partial eta-square statistic $\left(\eta^{2}\right)$ was given as a measure of effect size. $R^{2}$, adjusted for model complexity, was calculated as a measure of goodness of fit. The relationship between female $C L$ and the estimated pleopodal fecundity was described by linear regression, with $C L$ as independent variable. Finally, we used principal component analysis (PCA) to plot different populations of the white-clawed crayfish species complex according to life-history traits $\left(\phi^{\prime}\right.$, $k, t_{\max }$, and $C L_{\infty}$; as summarized in Scalici et al., 2010 and Ghia et al., 2015).

\section{RESULTS}

\section{> DISTRIBUTION}

White-clawed crayfish were detected at 15 of the 29 sampling sites along a continuous river stretch of $4.5 \mathrm{~km}$ (Figure 1). Frequency of capture at presence sites was 0.42 (95\% $\mathrm{Cl}$ : $0.24-0.59)$. The probability of capturing at least one crayfish at a positive sampling site was 1.0 (95\% Cl: 0.996-1.000), which indicates a negligible probability of false negatives.

The upper distribution limit (371 $\mathrm{m}$ a.s. I.) was approximately $300 \mathrm{~m}$ downstream the confluence of the small tributary stream Oberrieder Bach (Ob; Figure 1), which features a previously known abundant white-clawed crayfish population (Biss, 1996; Beyerle, 2000). The lower distribution limit (346 m a.s.l.) was situated in a settlement area, where artificial bank structures gradually replace the natural riparian vegetation.

Apart from the River Brugga, we detected white-clawed crayfish in a short stretch of one artificial outflow, the canal Mühlbach, and in lower reaches of two small tributary streams, the Dietenbach and the Geroldsbach (Db and Gb, respectively; Figure 1). In Gb we also detected a population of endangered stone crayfish (Austropotamobius torrentium). Stone crayfish exclusively inhabited the headwater section of $\mathrm{Gb}$, followed by a short overlap zone with a syntopic co-occurrence of both Austropotamobius species (Figure 1). 


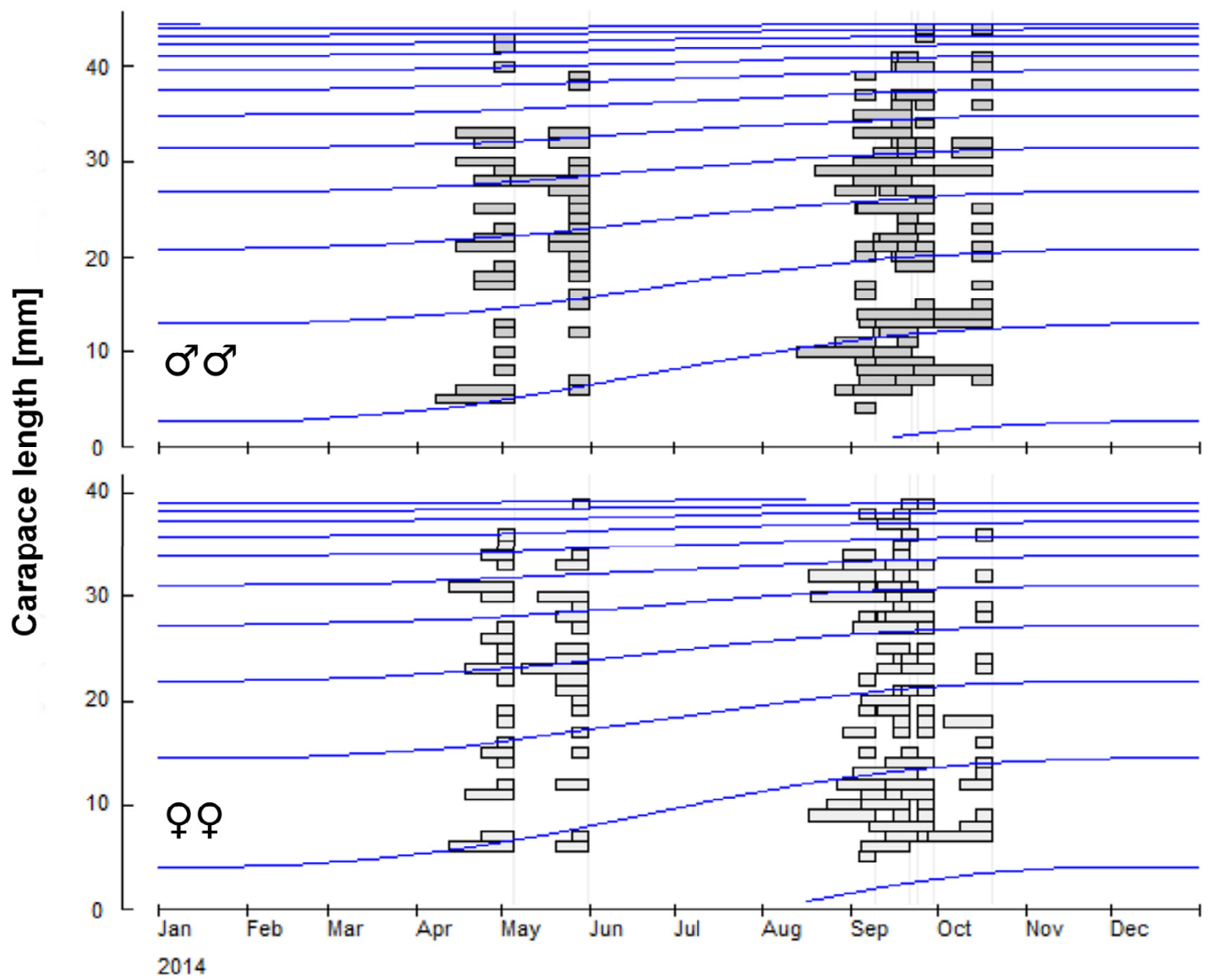

\section{Figure 2}

VBGF (blue line) and size frequency distribution (horizontal grey bars) of male (top) and female (bottom) A. pallipes in the River Brugga, southwestern Germany $(N=452)$. VBGF parameters are summarized in Table I.

\section{> POPULATION STRUCTURE, ABUNDANCE AND ESTIMATED POPULATION SIZE}

A total of 455 white-clawed crayfish were captured from the River Brugga during the study period. The sex ratio was even (1.02 males: 0.98 females, Fisher exact test: $P=1.00)$ and there was no size difference between sexes (Mann-Whitney $U$ test: $U=23879, P=0.15$ ). $C L$ ranged from 4 to $44 \mathrm{~mm}$ in males $(N=230)$ and from 5 to $39 \mathrm{~mm}$ in females $(N=225)$. Five percent of the sampled individuals had lost or regenerated chelae, other injuries were found in $3 \%$ of the crayfish. Colonization by branchiobdellid worms was noticed in $3 \%$ of the individuals.

Mean abundance of white-clawed crayfish, as assessed by fixed-area sampling, was 1.4 (range: $1.1-1.6) \pm 0.2$ indiv. $\mathrm{m}^{-2}\left(95 \% \mathrm{Cl}: 1.2-1.6\right.$ indiv. $\left.\cdot \mathrm{m}^{-2}\right)$. Shelter occupancy averaged 0.42 (range: $0.35-0.60) \pm 0.1$ indiv. . shelter $^{-1}$.

\section{> GROWTH AND LIFE-HISTORY TRAITS}

Seasonal growth was described by using Von Bertalanffy's Growth Function (VBGF) and the resulting seasonal growth pattern . Size-frequencies of the Brugga-population are shown in Figure 2 for each sex. The obtained VBGF-parameters $\left(C L_{\infty}, k\right.$, and $\left.t_{0}\right)$ and their derivatives $\left(t_{\max }\right.$ and $\left.\phi^{\prime}\right)$ are summarized per sex in Table $\mathrm{I}$. 
Table I

VBGF-parameters (asymptotic size, CLo, curvature parameter, $k$, and initial condition parameter, $t_{0}$ ), longevity ( $\left.t_{\max }\right)$ and growth performance index $\left(\phi^{\prime}\right)$ of the A. pallipes population in the River Brugga, distinguished per sex.

\begin{tabular}{|l|c|c|c|c|c|}
\hline sex & CLo & $k$ & $t_{0}$ & $t_{\max }$ & $\phi^{\prime}$ \\
\hline Males & 46.2 & 0.27 & -0.20 & 10.9 & 2.8 \\
Females & 41.0 & 0.33 & -0.19 & 8.9 & 2.7 \\
\hline
\end{tabular}

\section{Table II}

Predictors of chelae length, as assessed by multiple linear regression analysis (adjusted $R^{2}=0.96$ ). $C L$ means carapace length and SE indicates the standard error of the coefficient estimate. $F$ and $P$ are given by analysis of variance (Type II tests) and indicate whether inclusion of the predictor significantly improves model fit. Partial eta-square $\left(\eta^{2}\right)$ gives the effect size. Asterisks show the significance level: * $P<0.05$ and ${ }^{* *}-P<0.001$. Coefficients printed in grey are part of an interaction term and should be carefully interpreted. Please refer to Figure $3 B-E$ for details.

\begin{tabular}{|c|c|c|c|c|c|c|}
\hline Predictor & Coefficient & $S E$ & $\eta^{2}$ & $F$ & \multicolumn{2}{|l|}{ P } \\
\hline$C L$ & 0.56 & 0.03 & 0.84 & 2409.8 & $<0.001$ & 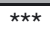 \\
\hline Sex & -0.69 & 0.57 & 0.15 & 77.0 & $<0.001$ & *** \\
\hline Maturity $(C L \geqslant 25 \mathrm{~mm})$ & -7.06 & 1.73 & 0.01 & 6.5 & 0.011 & * \\
\hline$C L: s e x[m a l e]$ & 0.07 & 0.04 & 0.05 & 23.6 & $<0.001$ & *** \\
\hline CL:maturity[adult] & 0.32 & 0.06 & 0.35 & 234.7 & $<0.001$ & *** \\
\hline Sex[male]:maturity[adult] & -8.90 & 2.08 & 0.00 & 0.0 & 0.92 & \\
\hline$C L: \operatorname{sex}[$ male]:maturity[adult] & 0.34 & 0.07 & 0.05 & 20.8 & $<0.001$ & *** \\
\hline
\end{tabular}

\section{> RELATIONSHIP BETWEEN CHELAE LENGTH AND CARAPACE LENGTH}

No interaction term or predictor variable was dropped from the MLM during stepwise backward selection based on AIC and the full model was therefore considered as minimum adequate model $\left(\mathrm{AIC}=523.3\right.$, residual standard error $=1.77, F_{7 / 444}=1480, P<0.001$, and adjusted $\left.R^{2}=0.96\right)$. $P L$ was positively related to $C L$, but depended also on sex and maturity (analysis of variance: $P<0.05$; Table II; Figure 3). The interaction between $C L$, sex, and sexual maturity was highly significant, which indicates that chelae length increases significantly faster in adult males (Figure 3A) than in females and juvenile crayfish (Figure 3B-3E). Based on effect size $\left(\eta^{2}\right), P L$ mostly depends on $C L$, followed by the interaction between $C L$ and maturity, and sex (cf. Table II).

\section{> SIZE AT MATURITY, REPRODUCTION AND FECUNDITY}

The smallest captured female with attached eggs had a CL of $25 \mathrm{~mm}$ and all females $\geqslant 27 \mathrm{~mm}$ $C L$ captured during the spring sampling period (mid-April to mid-June) were ovigerous. From Figure 3 and the MLM analysis of the relationship between $P L$ and $C L$ it can be concluded that males also mature at approximately $25 \mathrm{~mm} C L$ or slightly below. Fifty-two percent of the sampled crayfish featured a $C L<25 \mathrm{~mm}$ and were therefore considered as juveniles.

During the spring sampling, when females carry eggs (Souty-Grosset et al., 2006), we captured a total of 29 females, which were considered as sexually mature ( $C L \geqslant 25 \mathrm{~mm})$. Twentyfour $(83 \%)$ of these females had attached eggs. The CL of ovigerous females averaged $31 \mathrm{~mm}$ (range: 25 to $39 \mathrm{~mm}$ ) and the number of estimated pleopodal eggs averaged $90 \pm 28$ (range: 60-135) per female. There was a significant correlation between $C L$ and the estimated number of eggs attached to the pleopods (Pearson correlation: $N=22 ; R=0.79 ; P \leqslant 0.001$; Figure 4). Two clutches were excluded from the correlation, because the eggs had an orange color, which indicates that they were not viable (Pöckl, 1998a). Throughout the study period, none of the captured females featured hatchlings, albeit embryos were almost fully developed by mid-June. 

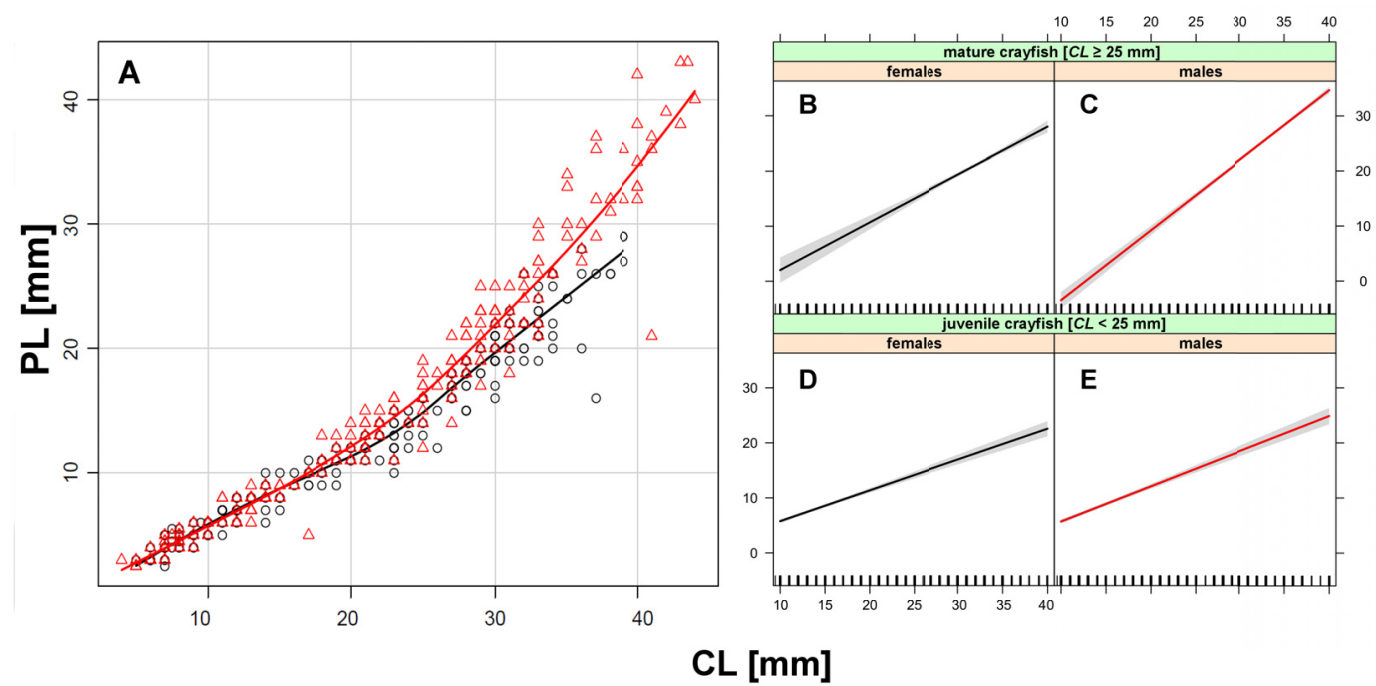

\section{Figure 3}

A - Relationship between carapace length (CL) and chelae length (PL) in male (triangles) and female (circles) white-clawed crayfish $(N=452)$. Solid lines represent trend lines given by locally weighted scatterplot smoothing (LOESS). B-E - Effects plot of the MLM used to describe the data with sex, maturity $(C L \geqslant 25 \mathrm{~mm})$ and $C L$ as independent variables (adjusted $\left.R^{2}=0.96\right): B$ - mature females; $C$ - mature males; $D$ - juvenile females; and $E$ - juveniles males. See Table II for MLM statistics.

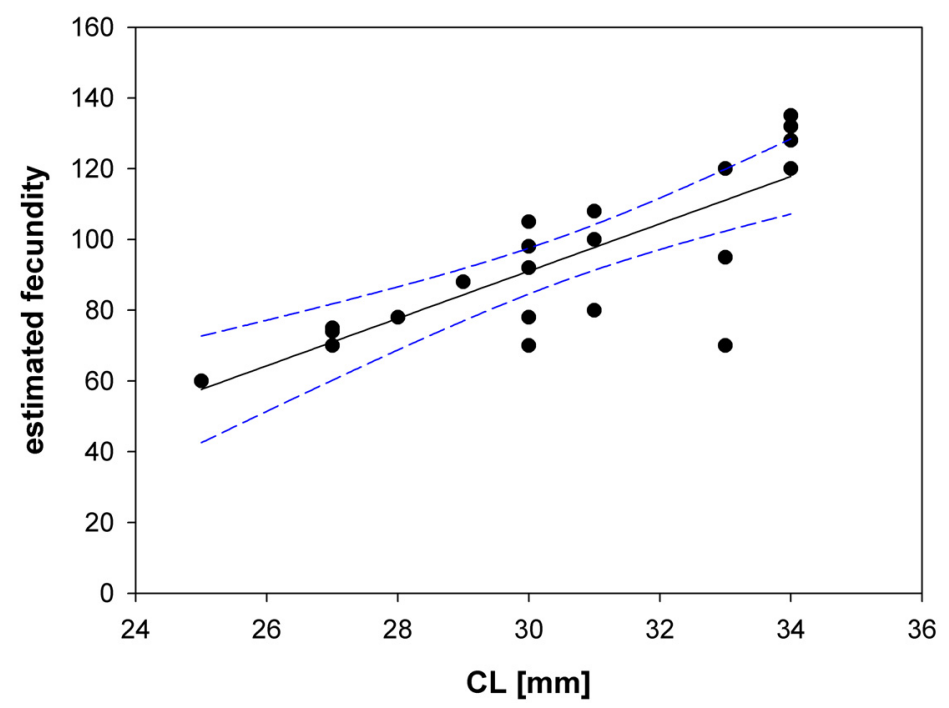

\section{Figure 4}

Fecundity of $A$. pallipes females captured from the River Brugga in relation to carapace length. Trend line is given by linear regression $\left(R^{2}=0.62 ; P \leqslant 0.001\right)$ and hatched lines represent the $95 \%$-confidence interval.

\section{DISCUSSION}

\section{> DISTRIBUTION AND ABUNDANCE}

Owing to the cryptic lifestyle of crayfish and the fact that the River Brugga represents a complex water body with many hiding places, the $A$. pallipes population investigated in our study had remained undetected until recently. Nonetheless, in the course of the investigation we discovered a large, widespread population (cf. Figure 1). 
The colonized stretch started below the high-gradient headwater section of the River Brugga featuring a torrential character and ended where the river enters a settlement area. High water currents and low temperatures are presumably important factors in limiting the upstream distribution of the population. In particular, upstream of the population we measured water currents of up to $0.65 \mathrm{~m} \cdot \mathrm{s}^{-1}$ near the river bank, which clearly exceeds the range preferred by crayfish (up to approximately $0.30 \mathrm{~m} \cdot \mathrm{s}^{-1}$; Bohl, 1989; Beyerle, 2000; Gilly, 2002) and the values measured within the colonized stretch (up to $0.43 \mathrm{~m} \cdot \mathrm{s}^{-1}$ ). Moreover, Biss (1996) reported that the headwater section of the River Brugga is subject to substrate mobilization during high water flow events, which prevents permanent colonization by white-clawed crayfish (Laurent, 1988). The downstream limit of the population coincides with a settlement area, where artificial bank structures gradually replace the natural riparian vegetation. Here, the banks were directly surrounded by human dwellings with gardens and orchards, i.e. riparian land-use types which were previously shown to be negatively associated with white-clawed crayfish presence probability in a French population (Souty-Grosset et al., 2010).

Interestingly, we detected no crayfish in a 300-m stretch between the confluence of the stream Oberriederbach (Ob, Figure 1), which holds the previously known population, and the upstream limit of the newly discovered population in the River Brugga (cf. Figure 1). Although we cannot exclude the possibility of a false negative, i.e. due to very low crayfish density, the estimated detection probability of the used sampling method was fairly high and we suggest that crayfish were indeed absent from this 300-m stretch, probably due to high water currents. Exchange of individuals, and therefore gene flow between both populations seems likely, though, and suggests a meta-population structure. This is of relevance from a conservational point of view, because meta-population structure can decrease extinction risk (Hanski, 1998). In the case of the local extinction of a subpopulation, the vacant habitat can be re-colonized by immigrants from the remaining subpopulations. This offers, in theory, some protection against local extinction events that are caused by short-term deleterious forces, such as droughts during extreme climate events or point-source water pollution. However, further field data or genetic evidence is necessary to validate the hypothesis of a meta-population structure.

The mean crayfish abundance in the River Brugga, $\left(1.4 \mathrm{crayfish} \cdot \mathrm{m}^{-2}\right)$, as assessed by fixedarea sampling, falls within the range of densities reported from other white-clawed crayfish populations in Germany (0.8-2.3 crayfish $\cdot \mathrm{m}^{-2}$; unpubl. monitoring data, Fisheries Research Station, C. Chucholl) and the densities known from Ireland and France $\left(0.2-10\right.$ crayfish $\cdot \mathrm{m}^{-2}$; Matthews and Reynolds, 1995; Reynolds, 2002). Moreover, the collected data on distribution and abundance concordantly indicate that the population in the River Brugga ranks among the largest remaining populations in Germany (cf. Chucholl and Dehus, 2011) and could be used as a donor stock for re-stocking efforts - both aspects warrant a high conservation priority.

\section{> GROWTH AND LIFE HISTORY}

Using size-frequency distributions to estimate age cohorts and thereby growth in crayfish requires an adequate sample size. The dataset of our study exceeded the minimum of 200 specimens suggested by France et al. (1991) and the estimated life-history parameters are in good accordance with previous studies on white-clawed crayfish (cf. Scalici et al., 2010). In particular, the obtained growth performance indexes were identical to the values reported by other studies (Table III), which indicates that our growth parameter estimates are not biased (Pauly and Munro, 1984). Moreover, the sex ratio of the captured crayfish was even and there was no size difference between sexes, which suggests no sex-specific sampling bias.

Compared to the life-history parameters of populations in other European localities, the population in the River Brugga features a life history most similar to a population in France (summarized in Table III and Figure 5). White-clawed crayfish in the UK tend to grow larger and older than populations in France, Germany and central Italy, which is in accordance with latitudinal clines as suggested by Scalici et al. (2008). Interestingly, however, white-clawed crayfish in 


\section{Table III}

Comparison of life-history parameters of different A. pallipes populations in Europe (cf. Figure 5).

\begin{tabular}{|l|c|c|c|c|c|c|c|}
\hline Country/region & Taxon & Sex & $\phi^{\prime}$ & $C L \infty$ & $k$ & $t_{\max }$ & Reference \\
\hline UK, Central South & A. pallipes s. str. & $\mathrm{m}$ & 2.8 & 54.2 & 0.21 & 14.3 & Pratten (1980)\# \\
England & & $\mathrm{f}$ & 2.7 & 45.6 & 0.26 & 11.5 & \\
\hline UK, East of England & A. pallipes s. str. & $\mathrm{m}$ & 2.8 & 55.1 & 0.23 & 13.0 & Hogger (1984)\# \\
& & $\mathrm{f}$ & 2.8 & 51.4 & 0.25 & 12.5 & \\
\hline NW France, Normandy & A. pallipes s. str. & $\mathrm{m}$ & 2.9 & 48.7 & 0.30 & 10.0 & Neveu (1996)\# \\
& & $\mathrm{f}$ & 2.7 & 40.4 & 0.33 & 9.1 & \\
\hline Central Italy, Tuscany & 'A. italicus' & $\mathrm{m}$ & 3.1 & 57.9 & 0.34 & 8.8 & Brusconi \\
& & $\mathrm{f}$ & 3.0 & 52.1 & 0.37 & 8.1 & et al. (2008) \\
\hline Central Italy, Lazio & 'A. italicus' & $\mathrm{m}$ & 2.8 & 42.4 & 0.35 & 7.8 & Scalici \\
& & $\mathrm{f}$ & 2.8 & 39.0 & 0.41 & 7.1 & et al. (2008) \\
\hline Northern Italy & 'A. italicus' & $\mathrm{m}$ & 2.8 & 63.0 & 0.16 & 17.9 & Ghia \\
& & $\mathrm{f}$ & 2.7 & 52.0 & 0.19 & 15.1 & et al. (2015) \\
\hline
\end{tabular}

\# VBGF parameters derived by Scalici et al. (2008)

${ }^{*}$ Carapace length estimated from total length data using linear regression

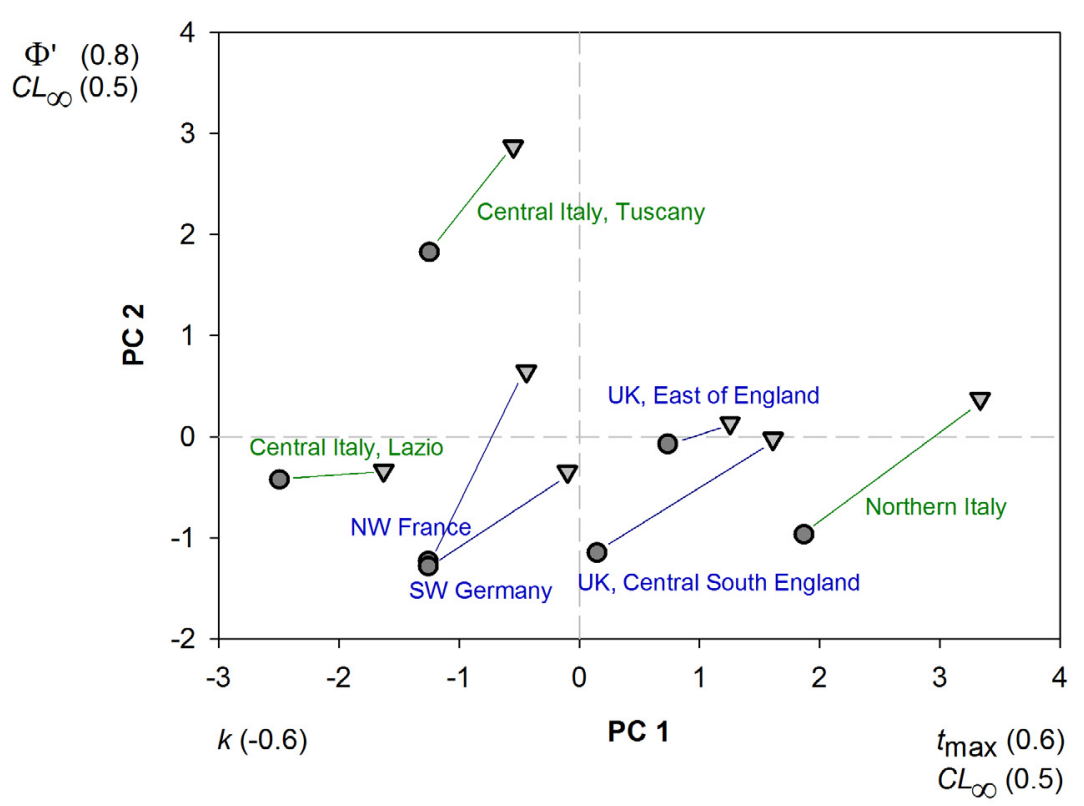

\section{Figure 5}

Ordination from PCA of white-clawed crayfish populations according to life-history traits (as summarized in Table III). Males are shown as triangles, dots represent females. Populations of the western lineage (A. pallipes s. str.) are depicted in blue, populations of the southern lineage (A. 'italicus') are shown in green. Life-history traits with loadings $\geqslant|0.5|$ are shown at the corresponding axes (loading in brackets). Cumulative proportion of explained variance $=0.99$.

the Alpine climatic zone in northern Italy were recently shown to grow even larger and older than in the UK (Ghia et al., 2015), with an estimated longevity in males of up to $18 \mathrm{y}$, as opposed to values between 10 and 13 y reported for French, German and UK populations, and values between 8 and 9 y in central Italy (Table III, Figure 5). This strongly points to temperature as the primary factor governing white-clawed crayfish life history (Lowery, 1988; Ghia et al., 2015).

Growth of crayfish is generally influenced by temperature and increases with temperature up to a species-specific optimum (Reynolds, 2002). In reared $A$. pallipes the optimal growth 
occurs at a temperature of $20^{\circ} \mathrm{C}$ whereas lowest was observed at $13^{\circ} \mathrm{C}$ (Policar et al., 2010); at water temperatures below $10^{\circ} \mathrm{C}$ growth ceases (Pratten, 1980). Water temperatures in the River Brugga exceeded $10{ }^{\circ} \mathrm{C}$ in May and reached $16{ }^{\circ} \mathrm{C}$ in summer, which, according to Arrignon (1996), is the optimum for the species in France. In a comparative study of habitat parameters of 11 German streams with white-clawed crayfish, Gilly (2002) found mid-summer temperatures between 17 and $20^{\circ} \mathrm{C}$, i.e. slightly above those observed in the River Brugga. Climate-induced variability in growth is likely to affect other life-history traits, such as the onset of sexual maturity (Reynolds, 2002). Irish and British populations of $A$. pallipes attain sexual maturity between 22 and 27 mm CL (Moriarty, 1973; Brewis and Bowler, 1982; O'Keeffe, 1986; Woodlock and Reynolds, 1988) and Alpine populations in northern Italy mature at $27 \mathrm{~mm}$ CL (Ghia et al., 2015). The A. pallipes from the River Brugga in Germany were sexually mature at $25 \mathrm{~mm} \mathrm{CL}$, which corresponds to the previously reported values. Ghia et al. (2015) suggested that maturity in white-clawed crayfish is mostly related to size rather than age. Populations experiencing different growth rates may therefore also exhibit a different age at maturity and cold temperatures may delay maturity (Reynolds, 2002). For instance, under controlled conditions with optimal temperatures, some $A$. pallipes females had been able to lay eggs at an age of 16 months (Policar et al., 2010), whereas age at maturity in Alpine populations with slow growth rates was estimated at three years (Ghia et al., 2015). Based on the estimated growth parameters, white-clawed crayfish in the River Brugga probably mature at an age of $2+$, which coincides with the age at maturity reported for Irish, British, and French populations (Pöckl, 1998b, and citations therein).

Apart from climate-induced variability in life-history traits, Figure 5 also illustrates the wellknown phenomenon of larger asymptotic size and higher longevity in males, which also involves a higher growth performance. Sex-specific growth patterns are known from a number of crayfish species, including white-clawed crayfish, and are probably driven by slower growth of adult females due to a lower moult frequency because female crayfish cannot moult while bearing eggs (Reynolds, 2002; Scalici et al., 2010; Ghia et al., 2015). Furthermore, moult increments of mature females are smaller than those of males because of the high energetic demands of egg production coupled with a feeding inhibition while bearing eggs (Reynolds, 2002).

Finally, the estimated pleopodal fecundity of the ovigerous white-clawed crayfish females captured from the River Brugga (60-135 eggs.female ${ }^{-1}$ ) is in good accordance with the fecundity ranges reported by Pöckl (1998a) and Souty-Grosset et al. (2006), namely 50-120 and 50-200 eggs. female ${ }^{-1}$, respectively. The linear increase of fecundity with female size represents a well-documented phenomenon in crayfish (Souty-Grosset et al., 2006). The presence of almost fully developed embryos by mid-June suggests a hatching period of mid to late June, similar to populations in northern Italy (Ghia et al., 2015) and southern England (Holdich, 2003), but a little later than populations in central Italy (Gherardi et al., 1997) and earlier than in populations in northern England, releasing their juveniles in August (Holdich, 2003). Overall, the obtained size-frequency distributions, life-history traits and fecundity estimates, as well as the high proportion of ovigerous females concordantly suggest the presence of a wellstructured, vital white-clawed crayfish population in the River Brugga.

\section{> OVERLAP WITH STONE CRAYFISH}

A surprising finding of the crayfish survey was the short syntopic co-occurrence of stone crayfish and white-clawed crayfish in the small tributary stream Geroldsbach (Gb; Figure 1). Stone crayfish exclusively inhabited the headwater section of Gb, whereas white-clawed crayfish were found in the lower reach, where we also detected the overlap zone (cf. Figure 1).

This is remarkable because, according to our knowledge, there exist no previous reports of a natural overlap between the western lineage of white-clawed crayfish and stone crayfish. The rare cases of synoptic co-occurrence between white-clawed crayfish and stone crayfish that we are aware of either originate from introduction of white-clawed crayfish, such as in a small pond in Switzerland (Stucki and Zaugg, 2011) and Lake Plansee in Austria 
(Füreder and Machino, 1995), or refer to the southern lineage of white-clawed crayfish, such as in the River Krka on the Dalmatian coast in Croatia (Laurent, 1988). This is despite the fact that both species have largely comparable habitat requirements (Gilly, 2002) and occur in close proximity in Switzerland and Germany, as well as possibly in Alsace, France (Laurent, 1988). While there is a well-defined, distinct distribution border between both species in Switzerland, with $A$. pallipes s. str. inhabiting the western part of the country (cf. Figure 1), the situation in southwestern Germany seems unique because of a sympatric range overlap in a whole catchment area (highlighted in red in Figure 1). Within this catchment both species occur in tributary streams of the same rivers, in some areas even in alternating sequence in adjacent tributaries (cf. Chucholl and Dehus, 2011). But even within this sympatric range, there has yet been no record of both species from the same stream (cf. Gilly, 2002).

In fact, the distribution pattern, both at the stream and catchment level, strongly points to competitive exclusion between the sister taxa. This notion is supported by the displacement of resident stone crayfish by introduced A. "italicus" in Tyrol, Austria (Sint et al., 2006). Gilly (2002) compared hydro-morphological and physico-chemical properties of white-clawed crayfish and stone crayfish streams in the sympatric German range and found high overlap in all habitat features. The only significant differences related to stone crayfish occurring at higher slopes and at shorter distance to springs. This finding is corroborated by the situation encountered in our study and a similar case in another small stream of the River Dreisam catchment that became known in the meantime. Overall, stone crayfish may be better adapted to extreme conditions in headwater streams, despite considerable niche overlap with white-clawed crayfish (cf. Gilly, 2002).

\section{CONCLUSION}

In summary, our study provides first insights into the population ecology of criticallyendangered white-clawed crayfish in Germany and documents for the first time a short natural overlap zone with stone crayfish. The estimated life-history traits emphasize the $K$-selected life history of white-clawed crayfish, i.e. a slow life cycle, high longevity and low fecundity. This becomes particularly apparent when compared to the more $r$-selected NICS, which, by contrast, feature a rapid life cycle and high fecundity (cf. Souty-Grosset et al., 2006; Chucholl, 2012). The syntopic occurrence with stone crayfish raises the question of ecological niche competition. Finally, our results may serve as a basis for monitoring and conservation of the species in the River Brugga, which features one of the largest remaining occurrences in Germany.

\section{ACKNOWLEDGEMENTS}

We are in debt to Karl-Otto Nagel for invaluable advice on crayfish occurrences and Julius Troschel for kindly providing literature. We thank Carola Sigle and Gerhard Bauer for various supports throughout the study and helpful comments on the manuscript. The helpful comments and suggestions made by two anonymous reviewers are also gratefully acknowledged. The views expressed in this article are those of the authors and not necessarily those of their parent organizations.

\section{REFERENCES}

Arrignon J., 1996. L'écrevisse et son élevage, 3rd edition. Lavoisier - Technique \& Documentation, Paris, $230 \mathrm{p}$.

Beyerle M., 2000. Charakterisierung einer Dohlenkrebspopulation. State examination thesis at the University of Freiburg, Freiburg, $51 \mathrm{p}$. 
Biss R., 1996. Gewässerentwicklungskonzept Brugga - Makrozoobenthos und Flusskrebse. Gesellschaft für Hydrologie u. Geowissenschaften, Buchenbach, 71 p.

Bohl E., 1989. Ökologische Untersuchungen zur Entwicklung von Zielvorstellungen des Gewässerschutzes. Untersuchungen an Flusskrebsbeständen. Schriftenreihe der Bayerischen Landesanstalt für Wasserforschung, Wielenbach, $237 \mathrm{p}$.

Brewis J.M. and Bowler K., 1982. The growth of the freshwater crayfish (Austrapotamobius pallipes) in Northumbria. Freshwater Biol., 12, 443-452.

Brusconi S., Renai B., Scalici M., Souty-Grosset C. and Gherardi F., 2008. Stock assessment in the threatened crayfish Austroptamobius italicus in Tuscany (Italy): implications for its concersation. Aquat. Conserv., in press.

Chucholl C., 2012. Understanding invasion success: life-history traits and feeding habits of the alien crayfish Orconectes immunis (Decapoda, Astacida, Cambaridae). Knowl. Manag. Aquat. Ecosyst., 404.

Chucholl C., 2014. Ausbreitungssperren für invasive Signalkrebse zum Schutz stark gefährdeter heimischer Flusskrebse in der Bottwar. AUF AUF, 2, 30-33.

Chucholl C. and Dehus P., 2011. Dohlenkrebs. In: Chucholl C. and Dehus P. (eds.), Flusskrebse in BadenWürttemberg, FFS, Langenargen, $39-42$.

Chucholl C. and Schrimpf A., 2015. The decline of endangered stone crayfish (Austropotamobius torrentium) in southern Germany is related to the spread of invasive alien species and land-use change. Aquatic Conserv: Mar. Freshw. Ecosyst., DOI: 10.1002/aqc.2568.

Chucholl C., Mrugala A. and Petrusek A., 2015. First record of an introduced population of the southernlineage of white-clawed crayfish (Austropotamobius 'italicus') north of the Alps. Knowl. Manag. Aquat. Ecosyst., 416, 10.

France R., Holmes J. and Lynch A., 1991. Use of size-frequency data to estimate the age composition of crayfish populations. Can. J. Fish. Aquat. Sci., 48, 2324-2332.

Füreder L. and Machino Y., 1995. Record of the white-clawed crayfish Austropotamobius pallipes (Lereboullet 1858) from Plansee (Tyrol, Austria). Ber. Nat. Med. Ver. Innsbruck, 82, 241-248.

Füreder L. and Reynolds J.D., 2004. Is Austrapotamobius pallipes a good bioindicator? Bull. Fr. Pêche Piscic., 370-371, 157-163.

Füreder L., Oberkofler B., Hanel R., Leiter J. and Thaler B., 2003. The freshwater crayfish Austropotamobius pallipes in South Tyrol: Heritage species and bioindicator. Bull. Fr. Pêche Piscic., 370-371, 79-95.

Füreder L., Gherardi F., Holdich D., Reynolds J., Sibley P. and Souty-Grosset, C., 2010. Austropotamobius pallipes. The IUCN Red List of Threatened Species. Version 2014.3. www. iucnredlist.org/ [23 May 2015].

Gayanilo Jr. F.C. and Pauly D., 1997. The FAO ICLARM stock assessment tools, FiSAT reference manual, FAO Computerized Information Series (Fisheries), FAO, Rome, 168 p.

Gherardi F., Villanelli F. and Dardi P., 1997. Behavioral ecology of the white-clawed crayfish Austropotamobius pallipes in a Tuscan stream: preliminary results. Freshwater Crayfish, 11, 182-193.

Ghia D., Fea G., Conti A., Sacchi R. and Nardi P.A., 2015. Estimating age composition in Alpine native populations of Austropotamobius pallipes complex. J. Limnol., DOI: 10.4081/jlimnol.2015.1139.

Gilly I., 2002. Vergleichende Untersuchungen abiotischer Faktoren von Gewässern mit Austropotamobius pallipes (LEREBOULLET 1858) und Austropotamobius torrentium (SCHRANK 1803), Ph.D. thesis, University of Freiburg, Freiburg, 59 p.

Hanski I., 1998. Metapopulation dynamics. Nature, 396, 41-49.

Hogger, J.B., 1984. A report on some of the first introductions of Pacifastacus leniusculus into the U.K. Freshwater Crayfish, 6, 134-145.

Holdich D., 2003. Ecology of the White clawed Crayfish. Conserving Natura 2000 Rivers Ecology Series No. 1 English Nature, Peterborough, $18 \mathrm{p}$.

Holdich D.M., James J., Jackson C. and Peay S., 2014. The North American signal crayfish, with particular reference to its success as an invasive species in Great Britain. Ethol. Ecol. Evol., 26, 232-262. 
Illies J., 1961. Versuch einer allgemeinen biozönotischen Gliederung der Fließgewässer. Int. Rev. Ges. Hydrobiol., 46, 205-213.

Laurent P.J., 1988. Austropotamobius pallipes and A. torrentium, with observations on their interactions with other species in Europe. In: Holdich D.M. and Lowery R.S. (eds.), Freshwater crayfish: biology, management and exploitation, University Press, Cambridge, 341-364.

Lowery R.S., 1988. Growth, moulting and reproduction, In: Holdich D.M. and Lowery R.S. (eds.), Freshwater crayfish: biology, management and exploitation. Croom Helm, London, 83-113.

Matthews M.A. and Reynolds J.D., 1995. A population study of the white-clawed crayfish Austropotamobius pallipes (Lereboullet) in an Irish reservoir. Biol. Environ., 95, 99-109.

Moriarty C., 1973. A study of Austropotamobius pallipes in Ireland. Freshwater Crayfish, 1, 57-67.

Neveu A., 1996. Caractéristique démographiques de stocks residuels de l'ecrevisse à pattes blanches. Austropotamobius pallipes (Astacidae), en Normandie. Cybium, 20, 75-93.

Nyström P., 1999. Ecological impact of introduced and native crayfish on freshwater communities: European perspectives. Crustacean issues, 11, 63-85.

O'Keeffe C., 1986. The ecology of two populations of the freshwater crayfish Austropotamobius pallipes (Lereboullet) in Ireland. PhD thesis, Department of Zoology, University of Dublin, Dublin, $254 \mathrm{p.}$

Pauly D. and David N., 1981. ELEFAN I, a BASIC program for the objective extraction of growth parameters from length-frequency data. Ber. Dtsch. Wiss. Kommission Meeresforsch., 28, 205-211.

Pauly D. and Morgan G.R., 1987. Length Based Methods in Fisheries Research, ICLARM, Manila, Filippines, and KIRSI, Safat, Kuwait, 468 p.

Pauly D. and Munro J.L., 1984. Once more on growth comparison in fish and invertebrates. Fishbyte, Newsletter Network Trop. Fish. Sci., 2, 21.

Peay S., 2003. Monitoring of the White-clawed crayfish, Austropotamobius pallipes. Conserving Natura 2000. Rivers Monitoring Series No. 1, English Nature, Peterborough, 52 p.

Pöckl M., 1998a. Fortpflanzung der Flusskrebse. Flusskrebse Österreichs. Stapfia, 58, 143-156.

Pöckl M., 1998b. Häutung und Wachstum von Flusskrebsen. Flusskrebse Österreichs. Stapfia, 58, $167-183$.

Policar T., Smyth J., Flanigan M., Kozák P. and Kouba A., 2010. Optimum water temperature for intensive production of Austropotamobius pallipes (Lereboullet) juveniles. Freshwater Crayfish, 17, 51-55.

Pratten D.J., 1980. Growth of the crayfish Austropotamobius pallipes (Crustacea: Astacidae). Freshwater Biol., 10, 401-412.

R Core Team, 2015. R: A language and environment for statistical computing. R Foundation for Statistical Computing, Vienna, Austria. http://www.R-project.org/. [2 January 2015].

Reynolds J.D., 2002. Growth and Reproduction. In: Holdich D.M. (ed.), Biology of Freshwater Crayfish. Blackwell Science, Oxford, 152-184.

Reynolds J.D. and Souty-Grosset C., 2012. Management of freshwater biodiversity: crayfish as bioindicators, Cambridge University Press, London, $384 \mathrm{p}$.

Scalici M. and Gherardi F., 2007. Structure and dynamics of an invasive population of the red swamp crayfish (Procambarus clarkii) in a Mediterranean wetland. Hydrobiologia, 583, 309-319.

Scalici M., Belluscio A., Gibertini G., 2008. Understanding population structure and dynamics in threatened crayfish. J. Zool., 275, 160-171.

Scalici M., Chiesa S., Scuderi S., Celauro D. and Gibertini G., 2010. Population structure and dynamics of Procambarus clarkii (Girard, 1852) in a Mediterranean brackish wetland (Central Italy). Biol. Invasions, 12, 1415-1425.

Sint D., Dalla via J. and Füreder L., 2006. The genus Austropotamobius in the Ausserfern region (Tyrol, Austria) with an overlap in the distribution of $A$. torrentium and $A$. pallipes populations. Bull. Fr. Pêche Piscic., 380-381, 1029-1040.

Souty-Grosset C., Holdich D.M., Noel P.Y., Reynolds J.D. and Haffner P. (eds.), 2006. Atlas of Crayfish in Europe. Museum national d'Histoire naturelle, Paris, Patrimoines naturels, 64, $187 \mathrm{p}$.

Souty-Grosset C., Hardy V., Raimond R. and Ollivier L., 2010. Land Use in Headwaters and the Distribution of Native White-clawed Crayfish, Austropotamobius pallipes (Lereboullet), in a Stream from the Poitou-Charentes Region, France. Freshwater Crayfish 17, 29-34. 
Stenroth P., Holmqvist N., Nyström P., Berglund O., Larsson P. and Graneli W., 2008. The influence of productivity and width of littoral zone on the trophic position of large-bodied omnivore. Oecologica, 156, 681-690.

Streissl F. and Hödl W., 2002. Habitat and shelter requirements of the stone crayfish Austropotamobius torrentium Schrank. Hydrobiologia, 477, 201-208.

Stucki T.P., 2002. Differences in life history of native and introduced crayfish species in Switzerland. Freshwater Crayfish, 13, 63 -82.

Stucki P. and Zaugg B., 2011. Aktionsplan Flusskrebse Schweiz. Bundesamt für Umwelt. UmweltVollzug Nr. 1104, BAFU, Bern, 61 p.

Troschel H.J., 1997. Distribution and ecology of Austropotamobius pallipes in Germany. Bull. Fr. Pêche Piscic., 347, 639 -647.

Troschel H.J. and Dehus P., 1993. Distribution of crayfish species in the Federal Republic of Germany, with special reference to Austropotamobius pallipes. Freshwater Crayfish, 9, 390-398.

Woodlock B. and Reynolds, J.D., 1988. Reproduction in an Irish lake population of the crayfish Austropotamobius pallipes (Lereboullet). Freshwater Biol., 19, 79-86.

Cite this article as: F. Wendler, R. Biss and C. Chucholl, 2015. Population ecology of endangered white-clawed crayfish (Austropotamobius pallipes s. str.) in a small rhithral river in Germany. Knowl. Manag. Aquat. Ecosyst., 416, 24. 